\title{
E-Map History in Geographical Learning of History in 4.0 era to Historical Education Students
}

\author{
Lukitaningsih $^{1}$, Ponirin ${ }^{2}$, Syarul Nizar ${ }^{3}$ \\ \{lukitaningsih@unimed.ac.id,ponirin@Unimed.ac.id, syarulnizar@unimed.ac.id\} \\ Department of History Education, Universitas Negeri Medan. \\ J1. Willem Iskandar Psr V Medan Estate, Medan, 20221, Indonesia
}

\begin{abstract}
This research is development research that aims to produce a historical map e-book product to help students and lecturers in the course of historical geography to answer the challenges of Era 4.0, under the 2013 KKNI curriculum requirements, and to know the effectiveness of the developed historical e-book map products. The subjects of this study were the $3^{\text {rd }}$-semester students that taking historical geography courses in the Department of Historical Education. The development model used is the Borg and Gall development model. This research was conducted through three (3) stages, namely: (1) identification of problems, (2) design, and (3) deployment. The results of the study showed that the e-book product which developed was valid through several stages of revision, the results of (1) grammar experts were in a very valid qualification (90\%), (2)material experts showed that the qualifications were very valid $(91 \%)$, and (3) the presentation experts on digital programs had a very valid qualifications (92\%), (1) practitioner assessment was in a very valid qualification (89\%), (2) practitioner assessment also showed a very valid qualification (90\%), (3) practitioner assessment was in a very valid qualification (89\%), and (4) practitioner assessment was in a very valid qualification (90\%). From all of the validator and practitioner assessments, it was found that the qualifications were very valid with an average value of $(90.13 \%)$. For the effectiveness of the module products tested on students, the following results obtained from the classical percentage of student learning outcomes, (1) one to one phase $88 \%$, (2) small group $89 \%$, and (3) $90 \%$ of field trials. Based on the trial, at the third meeting, the products have met the effectiveness of the students achieving a minimum classical competency of $88 \%$.
\end{abstract}

Keywords: Development, historical e-book map, historical geography

\section{Introduction}

The purpose of education, in general, is to prepare students for their future. Students are expected to be able to solve and overcome the problems of life that they faced in a way that is good, precise, and fast [5]. For this reason, life skill is needed by the students. Life skills are skills owned by a person to be brave to face life and its problems naturally without feeling pressured, then proactively and creatively seek and find solutions. There are four types of life skills, namely: (1) personal skills which include self-knowledge and rational thinking skills, (2) social skills 
including communication skills with empathy and cooperation skills, (3) academic skills, and (4) vocational skills [3]. To answer the challenges above, Universitas Negeri Medan improves student quality by implementing the 2018 curriculum (KKNI-2018). E-learning is used in the implementation of $2018 \mathrm{KKNI}$, so the learning tools carried out by the lecturers will be based on e-learning include books used by students in e-book based historical geography courses.

The 2018 curriculum (KKNI) was developed to prepare students to have the ability to communicate, to think critically and analyze, to characterize, to create and to overcome a problem, and to have a sense of responsibility towards the campus environment, and society. Therefore, learning outside of the classroom must be able to improve student competence in using ICT (information technology) [1]. Learning historical geography must be able to direct students actively in searching, processing, constructing and using their knowledge in solving a problem where the occurrence of an event and historical heritage through historical maps. Teaching materials used by students and lecturers in the 4.0 era must be accessible anywhere and anytime; this is very helpful in the process of learning historical geography courses.

Achievement of learning goals is determined by many factors. In addition to lecturers, other important factors are learning resources such as books, modules, teaching materials, etc. The learning tool in the historical geography course used by historical education students is a teaching material sheet that is adjusted to the topic, for the map used is not under the source at the time of the historical event occurred, because the map used is not a historical map but a general map. With the existence of e-learning based tools such as e-books, e-modules, e-media, and others, the learning process will run effectively, attractively and meaningfully so that learning objectives will be easily achieved. The available e-book maps used by students and lecturers have more specific material to history, so that when the content of the e-book analyzed it will support the 4.0 learning demands of the 2018 KKNI.

Based on the problems stated above, then in the study of historical geography it is very important to improve the e-learning based books, so that the contents of the books are in accordance with KKNI-18 demands to face 4.0 era with 6 tasks including students doing critical journal reviews, critical book reviews, mini researches, engineering ideas, projects, plus daily tasks. One of the solutions is, it is necessary to develop teaching materials in the form of historical e-books that are used in teaching and learning processes in historical geography courses to generate student competencies that are creative, innovative, productive and relevant to the learning. Through the development of e-books, students will understand the concepts they learn through direct experience, and assist them in completing 6 tasks of the 2018 KKNI.

This is intended to provide a more meaningful presentation of historical geography material so that learning has more quality. It also can improve the learning process and can achieve the learning objectives that have been formulated. This research was conducted with the aims: first to produce an e-book of historical maps that meet the criteria in learning historical geography. The second is to describe the effectiveness of historical e-books usage. The third describes student learning outcomes through the development of historical e-books.

The rapid development of technology, information, and communication has pushed Universitas Negeri Medan (UNIMED) to utilize e-learning systems in facing the 4.0 era to increase the effectiveness and flexibility of learning. The development and usage of e-learning and historical geography learning are very limited, due to the lack of lecturers and students' mastery and inadequate internet access. 
E-learning is a type of teaching and learning process that enables teaching materials to be delivered to the students by using the internet or other computer networks as the media [4]. The application of the educational approach is carried out by using technology to answer the challenges in 4.0 eras so that the learning of historical geography can be built by the students themselves. The constructivism approach regards those students' constructs / builds their knowledge that they will have. The construction (development) of that knowledge is based on their own experiences or the experiences of others. An important element in this theory is that a person fosters his knowledge actively by comparing new information with his existing understanding. The learning materials provided must have links to the experiences of students to attract their interests. Constructivism has a close relationship with electronic learning (e-learning) because in e-learning students learn independently by using teaching materials delivered through the website [4].

According to Borg and Gall [8], educational development research is a process used to develop and validate educational products. The steps of this process are commonly referred as the R\&D cycle, which consists of studying the research findings related to the product to be developed, developing the product based on these findings, field testing in the setting where it will be used, and revising it to improve the deficiencies found in the stages of submitting testing. While the research development according to Dick and Carey has 10 stages as follows (1) analyze the need to identify objectives. In the initial stages, researchers need to conduct a needs analysis to determine the objectives of the program or product to be developed. In this needs analysis activity, researchers identify the priority needs that must be fulfilled immediately. Performance analysis is usually done to assess the problem and the root of the problem by doing interview, observation and small group discussion, (2) learning analysis, conducting learning analysis, includes skills, processes, procedures, and learning tasks to achieve learning objectives, (3) context analysis, including abilities, attitudes and initial learning characteristics in the learning setting, (4) formulating performance goals, formulating performance goals is done by describing general objectives into more specific goals in the form of performance or operational objectives, (5) developing instruments, developing assessment instruments, this directly related to specific objectives, (6) developing learning strategies, which are designed in relation to the product or design you wanted to develop, (7) develop and choose learning materials, (8) designing and evaluating, There are three fundamental phases in carrying out the evaluation, namely: a) One-toone trials, b) small group trials, c) field trials, i.e. these trials involve subjects in larger classes that are involving 2 schools, (9) doing learning revisions, these revisions are made to the process (learning), procedures, programs or products associated with the previous steps, and (10) designing and conducting summative evaluations, carried out with the aim to determine the level of effectiveness of the product, program or overall process compared to other products.

\section{Methods}

This study is development research (Research and Development) that produces products with a qualitative description approach. The product produced in this development research is an ebook of historical maps. The populations in this study were all students who took historical geography courses in a total of 100 people (three classes). While the samples in this study were 1 class, one class as an experimental class and 2 classes as a book trial class in the field, the selection was based on a purposive technique sampling. The research design used a Borg and Gall 
development model. The stages in this study were slightly modified which were adapted to the Borg and Gall development procedures. Development research divided into 3 stages, namely: (1) identification of problems, (2) design and (3) deployment. The researcher sought to adapt the Dick \& Carey's development model to the Borg and Gall development procedure. At the product evaluation stage, researchers only conduct a formative evaluation of the Dick \& Carey development model in Figure 1 below.
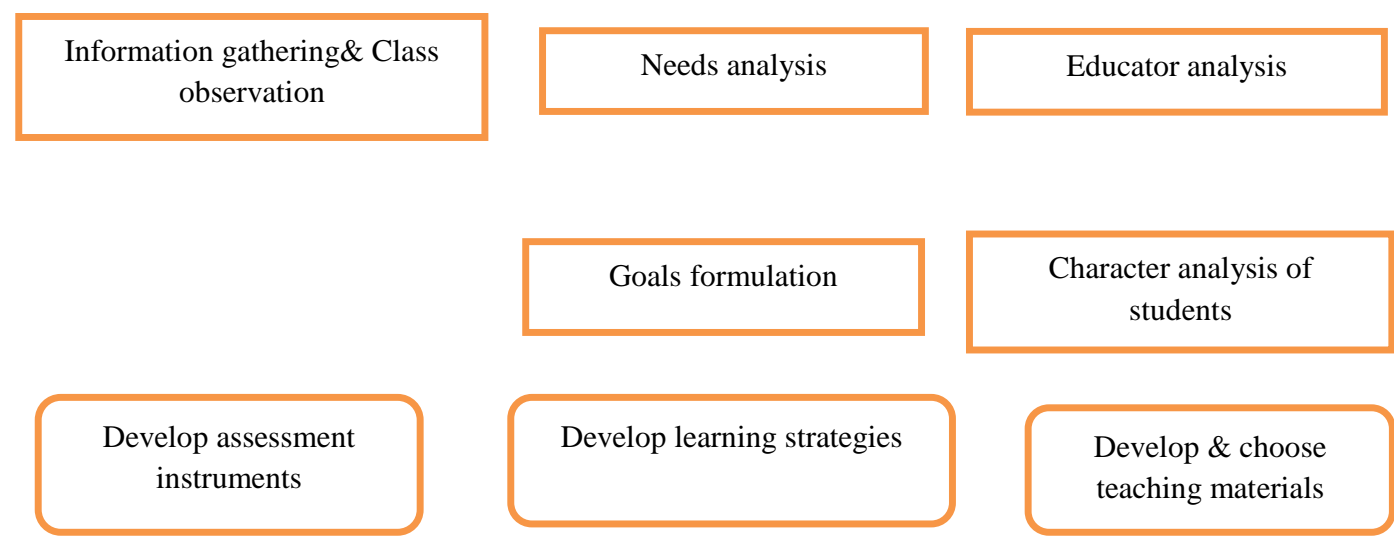

Develop \& choose teaching materials

\section{Experts Validation}

Product Testing

\section{Revision}

Product of Indonesian community study module based on local wisdom in North Sumatra

Fig. 1. Research and development model

Data collection techniques in this research carried out by tests, to measure aspects/cognitive domains of students. The test used in the form of multiple-choice tests with 10 item questions and non-test techniques for assessment or evaluation of student learning outcomes is done by distributing questionnaires, observations, interviews, and document checking. Data analysis techniques in this research are divided into 2 types, namely: 1 ) analysis of the data validity of the Indonesian community study module and 2) data analysis of student learning outcomes. Analysis of data module validity is used to answer the question "is the Indonesian community study module 
developed following local wisdom? The assessment criteria for each descriptor on the validation questionnaire sheet are as follows: Score $1=$ very poor/strongly disagree, score $2=$ poor/disagree, score 3 = good/agree, score $4=$ very good/strongly agree. Then the scores obtained are analyzed using the percentage score by using the formula:

Score Percentage $=$ Number of scores obtained $\times 100 \%$ Number of total scores

The classification of numbers in the form of percentage is then interpreted with qualitative sentences listed in Table 1 below.

Tabel 1. Module Grading Percentage Criteria

\begin{tabular}{cc}
\hline Achievement Level & Validity Level \\
\hline $85,01 \%-100 \%$ & Very valid, or can be used without revision \\
$70,01 \%-85 \%$ & It is quite valid, or can be used but needs a little revision \\
$50,01 \%-70,0 \%$ & Invalid, it is recommended not to be used because it needs \\
& major revisions \\
$01,00 \%-50,00 \%$ & Invalid, or may not be used \\
\hline
\end{tabular}

Data analysis of learning outcomes is used to answer the question "how is the effectiveness of the development of Indonesian community study modules based on local wisdom that has been developed on student learning outcomes. Scores obtained by students through learning outcomes tests are used to determine individual learning mastery and classical learning mastery of students. Individual completeness or student learning mastery is determined by the formula:

$$
\mathrm{KB}=\underline{\mathrm{T}} \times 100 \%
$$

Note: $\mathrm{KB}=$ Learning Mastery, $\mathrm{T}=$ total score achieved by students against all items, $\mathrm{T} 1=$ total score of all items [7]. As a standard of mastery learning used the standard set by the Dikti in the KKNI curriculum, where students are said to have learning mastery if the proportion of students' answers is correct or the percentage of mastery learning $\geq 70 \%$. To determine the mastery of learning classically used the formula:

$$
\text { PKK }=\frac{\text { Number of students who have mastered }}{\text { Total number of students }}
$$

Note: PKK =Classical Mastery Percentage [7]

A class is said to be master the study if in that class there are $80 \%$ of students who have achieved individual mastery. The results of the individual mastery and classical mastery analysis are then used to describe the quality of Indonesian community study modules based on local 
wisdom. After students' mastery in learning individually and classically had been achieved, accordingly, the modules developed have been effective and feasible to use.

\section{Result and discussion}

The stage of gathering information and class observations, about problems related to the historical geography teaching materials, information can be obtained by interviewing several lecturers who teach and students who take historical geography courses in the historical education department, then the researcher made a report to be analyzed based on the needs analysis of the data taken from classroom observations on the compatibility of the 2018 curriculum requirements with the book used. Then analyze each subject by identifying the main subjects taught, gathering and selecting relevant ones and reorganizing systematically. Then the educator is analyzed, the character of the students and formulating goals.

The second stage of design: (1) develops instruments assessment for students who were done when they had finished studying this teaching material. The cognitive and attitude or affective and psychomotor domains developed by students were also assessed to include c4, c5, c6. This module was used for 3 meetings. Each meeting is given an assignment in the form of a group discussion or independent and given value in the form of pretest and posttest, (2) develop learning strategies, and (3) develop and choose module learning materials.

The third stage is deployment, the instructional materials that have been designed are validated first by the expert team, then after being declared valid by the expert team is then validated by the practitioner. All validators provided an assessment by giving a score on each aspect of the assessment instrument. The activity phase starts from validation consisted: (1) the appropriateness of the language, (2) the appropriateness of the material, and (3) the appropriateness of the presentation, the results of the expert analysis of the module. The following product test and analysis of practitioners (lecturers) aim to determine the effectiveness of historical geography e-book products. Product testing is carried out systematically, starting from individual trials, small group trials, and field trials. Here will be explained the results of each analysis and trial of this study.

Tabel 2. The results of the analysis of grammar experts

\begin{tabular}{|c|c|c|c|c|c|}
\hline \multirow[t]{2}{*}{ No } & \multirow[t]{2}{*}{ Indicator } & \multirow[t]{2}{*}{ Descriptor } & \multicolumn{3}{|c|}{ Meetings } \\
\hline & & & I & II & III \\
\hline 1 & Accuracy & $\begin{array}{c}\text { The accuracy of sentence } \\
\text { structure }\end{array}$ & 2 & 3 & 3 \\
\hline & & The effectiveness of sentences & 3 & 3 & 4 \\
\hline 2 & Clarity of information & Understanding of messages & 3 & 3 & 3 \\
\hline \multirow[t]{2}{*}{3} & Conformity with the rules of the & Grammar accuracy & 2 & 3 & 3 \\
\hline & $\begin{array}{c}\text { Indonesian language is good and } \\
\text { right }\end{array}$ & Spelling accuracy & 2 & 2 & 3 \\
\hline 4 & Compatibility of student development & $\begin{array}{l}\text { An appropriate level of student } \\
\text { intellectual development }\end{array}$ & 3 & 3 & 4 \\
\hline
\end{tabular}




\begin{tabular}{cccc}
$\begin{array}{c}\text { Appropriate level of emotional } \\
\text { social development }\end{array}$ & 3 & 3 & 4 \\
$\begin{array}{c}\text { Total score } \\
\text { Percentage }\end{array}$ & 18 & 20 & 24 \\
& $78 \%$ & $89 \%$ & $91 \%$ \\
\hline
\end{tabular}

Based on the grammar expert's evaluation at the first meeting, the percentage is $78 \%$, and is in a less valid qualification, this means that in the language field it still needs improvement. At the second meeting the score obtained with a percentage of $89 \%$ or being in the qualification is quite valid, but there are still some things that must be improved, and at the third meeting the percentage of $91 \%$ with a score of 30 and being in a very valid qualification means that the module does not need to be revised again.

Tabel 2. Result of expert analysis.

\begin{tabular}{|c|c|c|c|c|c|}
\hline \multirow[t]{2}{*}{ No } & \multirow[t]{2}{*}{ Indicator } & \multirow[t]{2}{*}{ Descriptor } & \multicolumn{3}{|c|}{ Meetings } \\
\hline & & & 1 & 2 & 3 \\
\hline \multirow[t]{3}{*}{1} & \multirow[t]{3}{*}{ Material suitability } & Completeness of material & 2 & 3 & 3 \\
\hline & & The extent of the material & 3 & 3 & 3 \\
\hline & & Material depth & 2 & 3 & 3 \\
\hline \multirow[t]{2}{*}{2} & \multirow{2}{*}{ Material Accuracy } & The accuracy of the concept & 2 & 3 & 4 \\
\hline & & The accuracy of the terms & 3 & 4 & 4 \\
\hline \multirow[t]{3}{*}{3} & \multirow[t]{3}{*}{ Material expertise } & The suitability of the material scientifically & 3 & 3 & 4 \\
\hline & & Image and illustration & 3 & 3 & 3 \\
\hline & & Finesse & 2 & 3 & 3 \\
\hline \multirow[t]{5}{*}{4} & \multirow{5}{*}{$\begin{array}{l}\text { Content of local } \\
\text { wisdom material }\end{array}$} & Completeness of local wisdom material & 3 & 3 & 4 \\
\hline & & $\begin{array}{c}\text { The extent of the material is based on local } \\
\text { culture }\end{array}$ & 2 & 3 & 4 \\
\hline & & Depth of material based on local culture & 2 & 3 & 3 \\
\hline & & Amount & 27 & 34 & 38 \\
\hline & & Percentage & $71,46 \%$ & $87,327 \%$ & $\begin{array}{c}90,36 \\
\%\end{array}$ \\
\hline
\end{tabular}

Based on the table above, it can be seen that in the first validation the total score is 27 with a percentage $71.46 \%$, which is in a less valid qualification so the contents of the module need to be improved and developed or revised. At the second meeting, the percentage is $87.32 \%$, which is in quite a valid qualification, and in the third meeting, the score is 38 with a percentage of $90.36 \%$ which is in a very valid qualification and does not need to be revised.

Tabel 3. Results of expert presentation analysis

\begin{tabular}{lccccc}
\hline No & Indicator & Descriptor & \multicolumn{2}{c}{ Pertemuan } \\
& & & 11 & 111 \\
\hline 1 & Presentation technique & Systematic consistency of presentation & 3 & 3 & 4 \\
& & Serving rut & 3 & 4 & 4 \\
2 & Supporting the & Preliminary & 3 & 3 & 4
\end{tabular}




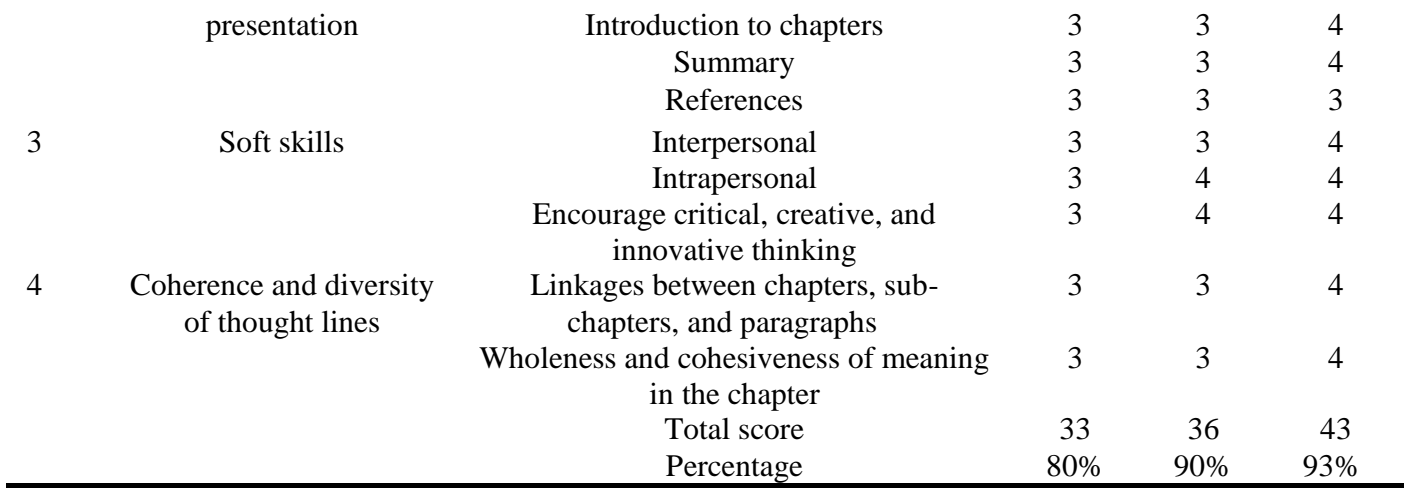

From the table above it can be seen that the validation score of experts in the field of presentation in the developed module at the first meeting with a percentage of $80 \%$ which means that it is in the qualification is quite valid, but there are still a few things that need to be improved. Furthermore, in the second meeting with a score of 36 was obtained with a percentage in $90 \%$, which means it was still in a sufficiently valid qualification, and in the third meeting the percentage increased in value, $93 \%$ was in a very valid qualification so that it was no longer revised.

\section{Conclusions}

The results of this study showed that the development of historical geography e-book based on a historical map is valid for the student to be used because it has been through the assessment and validation from several experts and practitioners. This conclusion was drawn based on the results of the expert's and practitioners' analysis consisted of grammar experts who were in very valid qualifications (80\%), content experts were in very valid qualifications (90\%), and presentation experts were invalidation (93\%). These developed modules are effective to use because student learning outcomes can be seen from the results of the module effectiveness analysis, based on product trials with three stages namely one to one, small groups, and field trials. The results of the trial at the one to one stage scored $78 \%$, at the small group stage obtained 85 , $42 \%$, the field trial stage involving classes a and b reg 2018 showed the percentage in $90.5 \%$. This means that the effectiveness indicator has been fulfilled.

\section{References}

[1] Abdul Haris Indrakusuma, D. (2016). E-Laerning: Teori dan Desain. jakarta: Rineka Cipta.

[2] Akbar, A. S. (2015). Instrumen Perangkat Pembelajaran. Bandung: : PT. Remaja Rosdakarya.

[3] Anwar. (2014). Pendidikan Kecakapan Hidup: Aplikasi. Bandung: Alfabeta.

[4] Darin E.Harley. (2011). Selling E-Learning American Sociaty for Training and Development.

[5] Dimyati, dkk. (2013). Belajar dan Pembelajaran. Jakarta: Rineka Cipta. 
[6] Sujana, N. (2009). Penialaian hasil Proses Belajar Mengajar. Bandung: Remaja Rosdakarya.

[7] Trianto. (2010). Mendesian Model pembelajaran Inovatif-Progresif. Jakarta: Kencana.

[8] Walter R. Borg \& Gall, M. D. (1983). Educational Research an information(4 thed). New York: Longman Inc. 